JOURNAL OF MANAGEMENT OF AQUATIC RESOURCES

Volume 2, Nomor 3, Tahun 2013, Halaman 170-179

Online di : http://ejournal-s1.undip.ac.id/index.php/maquares

\title{
JENIS KEPITING BAKAU (Scylla sp.) YANG TERTANGKAP DI PERAIRAN LABUHAN BAHARI BELAWAN MEDAN
}

\author{
Putri March F. Hia, Boedi Hendrarto, Haeruddin*)
}

Jurusan Perikanan, Fakultas Perikanan dan Ilmu Kelautan, Universitas Diponegoro Jl. Prof. H. Soedharto, SH, Tembalang Semarang. 50275 Telp/Fax (024) 7474698

\begin{abstract}
Abstrak
Labuhan Bahari Belawan Medan merupakan sebuah pulau yang terletak di Selat Malaka, Sumatera Utara. Salah satu sumberdaya perikanan di perairan tersebut adalah kepiting bakau, namun informasi mengenai kepiting bakau pada daerah ini masih kurang terutama jenis spesiesnya. Tujuan dari penelitian yang dilaksanakan pada bulan Januari-Februari 2012 ini adalah untuk mengetahui jenis dan morfologi kepiting bakau, kelimpahan yang mendominasi, dan mengetahui ekonomi kepiting bakau di perairan Labuhan Bahari Belawan Medan. Kepiting yang diteliti adalah kepiting bakau yang tertangkap di wilayah mangrove dan sekitar tambak yang ditumbuhi mangrove. Sampling dilakukan dengan alat tangkap bubu oleh masyarakat sekitar dinamakan bubu planet. Kepiting yang tertangkap diidentifikasi dan dilakukan pengukuran morfometrik kemudian menganalisa data yang didapatkan, dan wawancara nelayan untuk mengetahui nilai ekonomi kepiting bakau tersebut. Jumlah spesies kepiting bakau yang ditemukan adalah 3 spesies yaitu Scylla tranquebarica, Scylla serrata dan Scylla paramamosain, dengan kelimpahan yang mendominasi adalah Scylla tranquebarica sebesar 54,72\%, Scylla paramamosain sebesar 33,96\%, dan Scylla serrata sebesar 11,32\% di stasiun I (di kawasan mangrove), sedangkan di stasiun II (di luar kawasan mangrove) Scylla serrata 45,76\%, Scylla tranquebarica sebesar 33,98\%, dan Scylla paramamosain sebesar $15,25 \%$. Kepiting bakau yang biasanya dipasarkan adalah kepiting yang memiliki berat $\geq 200$ gram per ekor baik jantan maupun betina.
\end{abstract}

Kata Kunci : Kepiting Bakau (Scylla sp.), Jenis dan morfologi, Kelimpahan yang mendominasi

\begin{abstract}
Labuhan Bahari Belawan Medan is a little island found at Malaka Strait, North Sumatera. One of its fisheries resources is mud crab, but informations about mud crab in this area is still lacking, especially of species type. The purpose of this research was carried out in January-Februari 2012 were to find out the type and morphology of mud crabs, the abundance of dominant, and mud crabs economic in the Labuhan Bahari Coast Medan. Crabs samples were the mud crabs caught in mangrove areas and around the embankment overgrown with mangrove area. Sampling was done using trap by local people called bubu planet. Crabs that were identified and measured its morphometric, then analyzed the data. Fishermen were interviewed to find out economic value of mud crabs. This study found three species of mud crab i.e Scylla tranquebarica, Scylla serrata, and Scylla paramamosain, with abundance of dominant results at Station I (mangrove area) Scylla tranquebarica was 54,72\%, Scylla paramamosain was 33,96\%, and Scylla serrata 11,32\%, however at Station II (outside mangrove area) Scylla serrata was 45,76\%, Scylla tranquebarica was 33,98\%, and Scylla paramamosain was $15,25 \%$. Mud crabs are usually marketed in the weight of $\geq 200 \mathrm{gr}$ per mud crab both of male and female.
\end{abstract}

Keywords : Mudcrab (Scylla sp), Type and Morphology, Abundance of Dominant

\section{PENDAHULUAN}

Kepiting bakau adalah salah satu potensi yang ada dihutan mangrove dan belum banyak diketahui. Kepiting bakau termasuk sumberdaya perikanan pantai yang mempunyai nilai ekonomis penting dan mempunyai harga yang mahal (Afrianto dan Liviawaty, 1992). Selain peluang pasar yang cukup besar dengan harga tinggi menyebabkan bisnis kepiting menjadi penting, juga karena rasa daging kepiting yang gurih dan gizi yang tinggi. Setiap 100 gram daging kepiting mengandung protein sebesar 13,6 gram, lemak 3,8 gram dan air sebanyak 68,1 gram (Kordi, 2000). Oleh karena itu perrnintaan akan kepiting bakau terus meningkat baik untuk konsumsi dalam negeri maupun untuk keperluan ekspor. Permintaan yang terus meningkat tersebut dipenuhi melalui penangkapan di alam (Moosa et al, 1985).

Di Indonesia secara umum kepiting bakau diidentifikasi dengan nama spesies Scylla serrata. Nama spesies kepiting ini mungkin benar untuk kepiting yang ditemukan di wilayah tertentu, akan tetapi kemungkinan nama ini tidak benar. Perkembangan taksonomi dimungkinkan untuk membawa nama kepiting bakau dengan nama spesies yang lain dari Scylla 
serrata. Saat ini di dunia dikenal adanya empat spesies kepiting mangrove, yaitu Scylla serrata, Scylla paramomosain, S. tranquebarica, dan Scylla olivacea.

Dari informasi aspek ukuran, pertumbuhan kepiting yang tertangkap maka dapat diketahui distribusi kepiting yang tertangkap. Distribusi dapat dilihat berdasarkan jumlah (kelimpahan individu) dan ukuran yang tertangkap. Untuk lebih mengenal nama spesies kepiting mangrove dan mengetahui distribusi kepiting mangrove secara benar, maka akan dilakukan teknik sederhana dalam mengidentifikasi nama spesies kepiting mangrove, adapun identifikasi berikut didasarkan sifat atau karakter morfologinya agar mudah dimengerti.

Oleh karena itu diperlukan upaya pengelolaan sumberdaya kepiting bakau dengan mengetahui jenis, morfologi, ukuran, dan pertumbuhan kepiting bakau yang tertangkap di wilayah hutan mangrove perairan Labuhan Bahari Belawan Medan, serta ekonomi kepiting bakau itu sendiri. Data tersebut dapat membantu untuk mengetahui distribusinya, dengan melakukan pengambilan data dari 2 (dua) stasiun yaitu stasiun I berada di kawasan mangrove sedangkan di stasiun 2 (dua) berada di luar kawasan mangrove. Sebagai informasi pendukung diperlukan catatan tentang spesifikasi lingkungan atau habitat dimana kepiting tersebut hidup.

Tujuan penelitian kepiting bakau di perairan Labuhan Bahari Belawan Medan adalah untuk mengetahui hal-hal yang diperlukan untuk teknik identifikasi kepiting bakau, jenis dan morfologi kepiting bakau, mengetahui kelimpahan yang mendominasi, dan mengetahui ekonomi kepiting bakau.

\section{MATERI DAN METODE}

Lokasi sampling dilakukan dengan desain purposive random sampling, cara ini dilakukan untuk mendapatkan informasi dari 2 (dua) lokasi/stasiun yaitu stasiun I (di kawasan mangrove) dan II (di luar kawasan mangrove). Dari setiap stasiun masing-masing secara acak ditetapkan 5 (lima) sub stasiun dengan jarak antara sub stasiun satu dengan yang lainnya $\pm 20 \mathrm{~m}$. Alat yang digunakan untuk menangkap kepiting adalah perangkap yang oleh masyarakat lokal disebut bubu planet berbentuk lingkaran dengan diameter $50 \mathrm{~cm}$ ukuran mata jaring \pm 2 inch. Untuk mengukur morfometrik kepiting digunakan jangka sorong dengan ketelitian $0,1 \mathrm{~mm}$ serta timbangan untuk mengukur berat kepiting. Alat untuk mengukur parameter kualitas air, adalah thermometer air raksa, refraktometer dan $\mathrm{pH}$ meter.

Pengambilan data identifikasi dan pengukuran kepiting bakau dilakukan menggunakan kalifer dengan mengkur bagian-bagian kepiting, yaitu karapas, belahan depan, tulang dada dan kaki. Hal-hal yang diukur adalah lebar karapas atau Carapace width (CW), Internal carapace width (ICW), Carapace length (CL), Frontal median spine height (FMSH), Frontal width (FW), Inner carpus spine (ICS), dan Outer carpus spine (OCS).

Data yang diperoleh selanjutnya dianalisa sesuai hasil penelitian Keenan, et al (1998) dengan mengetahui karakter morfologi yang digunakan untuk identifikasi kepiting bakau, setelah itu data dibandingan dengan rata-rata dan standar deviasi dari tiga rasio mofologi dan bentuk duri antara mata untuk membedakan spesies kepiting bakau.

\section{HASIL}

Hutan mangrove tumbuh di sepanjang sungai yang melewati pulau, muara sungai yang menuju Selat Malaka. Pada waktu air pasang ketinggian air bisa mencapai 2 meter dan pada saat surut daerah pinggiran sungai akan kering. Untuk mengetahui jenis kepiting bakau di perairan ini, maka dilakukan pembagian stasiun menjadi dua stasiun. Stasiun I adalah daerah pinggir sampai hutan mangrove. Tumbuhan mangrove yang mendominasi adalah genera Rhyzophora dan Avicennie. Stasiun II adalah daerah tambak yang disekitarnya ditumbuhi tanaman mangrove yang mendominasi adalah dari genera Nypha. Kondisi parameter fisika dan kimia di kedua stasiun ini dapat dilihat pada Tabel 1. Suhu di stasiun I berada pada kisaran $27^{\circ} \mathrm{C}-29^{\circ} \mathrm{C}$ dan stasiun II berada pada kisaran $28^{\circ} \mathrm{C}-29^{\circ} \mathrm{C}$. Salinitas di kedua stasiun berbeda, salinitas di stasiun I sebesar 12-25 ppt dan di stasiun II sebesar 15-22 ppt, pH air di kedua stasiuan berada pada kisaran 6,5-7,2.

Jumlah tangkapan masing-masing stasiun yang diperoleh di perairan Labuhan Bahari Belawan Medan dapat dilihat dalam Tabel 2. Jumlah kepiting bakau yang paling sedikit tertangkap di stasiun I adalah tanggal 3 Februari 2012 dimana pada saat itu terjadi pasang mati, dan berikutnya tanggal 9 Februari 2012. Total kepiting yang tertangkap di kedua tanggal tersebut sebanyak 3 ekor dan jenis kepiting yang tertangkap juga sama yaitu $S$. paramamosain dan $S$. tranquebarica. Hasil tangkapan terbesar pada tanggal 8 Februari 2012 dengan total 12 ekor, dimana jenis kepiting yang tertangkap adalah $S$. tranquebarica dan S. paramamosain.

Untuk hasil tangkapan di stasiun II paling sedikit pada tanggal 5 Februari 2012 dengan total 3 ekor dan jenis kepiting yang tertangkap adalah S. serrata, sedangkan tangkapan terbesar pada tanggal 4 Februari 2012 dengan total 11 ekor dimana pada saat itu sedang terjadi surut mati, jenis kepiting yaang tertangkap adalah S. serrata dan S. tranquebarica.

Berat kepiting bakau yang tertangkap di setiap stasiun beragam. Berat kepiting bakau yang tertangkap di setiap stasiun beragam. Hasil penangkapan di stasiun I terdapat 53 ekor kepiting yang mempunyai berat antara 10-590 gr. Kepiting jantan adalah kepiting yang mendominasi di stasiun I dengan jumlah 26 ekor, berikutnya banci ada 21 ekor, dan betina ada 6 ekor kepiting. Hasil penangkapan di stasiun II terdapat 59 ekor kepiting mempunyai berat antara 100-810 gr. Di stasiun ini 
kepiting betina lebih mendominasi dengan jumlah 39 ekor, berikutnya jantan ada 15 ekor, dan banci ada 5 ekor kepiting. Kisaran berat dan jenis kelamin kepiting bakau di setiap stasiun dapat dilihat pada Gambar 1.

Tabel 1. Pengukuran fisika dan kimia perairan setiap stasiun penelitian

\begin{tabular}{|c|c|c|c|c|}
\hline \multirow{2}{*}{ No. } & \multirow[b]{2}{*}{ Parameter } & \multirow{2}{*}{ Satuan } & \multicolumn{2}{|c|}{ Stasiun } \\
\hline & & & I & II \\
\hline 1. & Suhu & ${ }^{\circ} \mathrm{C}$ & $27-29$ & $28-29$ \\
\hline 2. & Salinitas & ppt & $12-25$ & $15-22$ \\
\hline 3. & $\mathrm{pH}$ perairan & - & $6,8-7,2$ & $6,5-6,9$ \\
\hline
\end{tabular}

Menurut Keenan (1998) dalam mengidentifikasi jenis-jenis kepiting bakau, dapat dilihat dari warna pada karapas dan capit. Untuk lebih jelasnya dapat dilihat pada Tabel 2.

Dari 112 sampel yang tertangkap di kedua stasiun terdapat 3 jenis kepiting bakau yang memiliki persentase berbeda. Di stasiun I S. tranquebarica memiliki persentase terbesar yaitu 54,72\%, kemudian S. paramamosain 33,96\% dan S. serrata $11,32 \%$. Untuk stasiun II spesies yang mendominasi adalah S. serrata sebesar 45,76\%, kemudian S. tranquebarica 33,98\% dan S. paramamosain 15,25\%. Persentase jumlah spesies yang tertangkap di Perairan Labuhan Bahari dapat dilihat pada Gambar 2.

S. tranquebarica memiliki berat rata-rata 208,65 gram dengan nilai tengah 185 gram. Berat $S$. tranquebarica tersebar paling banyak pada kisaran 110-300 gram. S. serrata memiliki berat rata-rata 289,39 gram dengan nilai tengah 240 gram. Berat S. serrata tersebar paling banyak pada kisaran 165-340 gram, namun outlier 30 menunjukkan berat ekstrim sebesar 810 gram. Sedangkan $S$. paramamosain memiliki berat rata-rata 172,59 gram dengan nilai tengah 150 gram, berat tersebar paling banyak pada kisaran 80-200 gram, namun outlier 22 menunjukkan berat ekstrim sebesar 560 gram. Berat rata-rata tiap spesies yang tertangkap di kedua stasiun dapat di lihat pada Gambar 3.

S. tranquebarica memiliki lebar karapas rata-rata $101,85 \mathrm{~mm}$ dengan nilai tengah $105,70 \mathrm{~mm}$, dimana data tersebar paling banyak pada kisaran 81,06-119,05 mm. Lebar karapas S. serrata rata-rata 119,724 mm dengan nilai tengah 119,20 $\mathrm{mm}$, data tersebar paling banyak pada kisaran 110,50-130,08 mm, dan outlier 30 menunjukkan lebar karapas yang bisa dicapai sebesar 182,05 mm. Lebar karapas S. paramamosain rata-rata 94,79 $\mathrm{mm}$ dengan nilai tengah 92,05 $\mathrm{mm}$ dan data tersebar paling banyak pada kisaran 78,05-113,10 mm. Lebar karapas atau CW (Carapace Width) rata-rata tiap spesies yang tertangkap di kedua stasiun dapat di lihat pada Gambar 4.

Panjang ICW S. tranquebarica rata-rata $96,38 \mathrm{~mm}$ dengan nilai tengah $99,58 \mathrm{~mm}$ dan data tersebar paling banyak pada kisaran 77,087-112,587 mm. Untuk S. serrata rata-rata $114,08 \mathrm{~mm}$ dengan nilai tengah $113,05 \mathrm{~mm}$, data tersebar paling banyak pada kisaran 104,075-124,10 mm, dan outlier 30 menunjukkan panjang ICW yang bisa dicapai sebesar 170,10mm. Panjang ICW S. paramamosain rata-rata $89,64 \mathrm{~mm}$ dengan nilai tengah $87,10 \mathrm{~mm}$ dan data tersebar paling banyak pada kisaran 75,20-107,05 mm. Panjang ICW (Internal Carapace Width) rata-rata tiap spesies yang tertangkap di kedua stasiun dapat di lihat pada Gambar 5.

Tabel 2. Hasil tangkapan kepiting bakau setiap stasiun

\begin{tabular}{|c|c|c|c|c|}
\hline \multirow{2}{*}{ Sampling } & \multirow{2}{*}{ Tanggal } & \multicolumn{2}{|c|}{ Jumlah Tangkapan } & \multirow{2}{*}{ Keterangan } \\
\hline & & Mangrove $(n=50)$ & Luar Mangrove $(n=50)$ & \\
\hline 1 & 12 Januari 2012 & 9 & - & \multirow{11}{*}{$\begin{array}{l}\text { Pasang mati } \\
\text { Surut mati }\end{array}$} \\
\hline 2 & 13 Januari 2012 & - & 10 & \\
\hline 3 & 14 Januari 2012 & 4 & - & \\
\hline 4 & 03 Februari 2012 & 3 & - & \\
\hline 5 & 04 Februari 2012 & - & 11 & \\
\hline 6 & 05 Februari 2012 & 4 & 3 & \\
\hline 7 & 06 Februari 2012 & 11 & 5 & \\
\hline 8 & 07 Februari 2012 & 7 & 5 & \\
\hline 9 & 08 Februari 2012 & 12 & 10 & \\
\hline 10 & 09 Februari 2012 & 3 & 5 & \\
\hline 11 & 10 Februari 2012 & - & 10 & \\
\hline \multicolumn{2}{|c|}{ Jumlah individu } & 53 & 59 & \\
\hline
\end{tabular}


Tabel 3. Warna pada karapas dan capit kepiting bakau

\begin{tabular}{|c|c|}
\hline Spesies & Warna \\
\hline S. tranquebarica & $\begin{array}{l}\text { Karapas berwarna hijau tua dan coklat } \\
\text { Capit berwarna hijau ungu kecoklatan }\end{array}$ \\
\hline S. serrata & $\begin{array}{l}\text { Karapas berwarna Hijau kehitaman (gelap), hijau kecoklatan, dan hijau tua } \\
\text { Capit bewarna hijau kebiruan }\end{array}$ \\
\hline S. paramamosain & $\begin{array}{l}\text { Karapas berwarna hijau kecoklatan } \\
\text { Capit berwarna hijau kebiruan }\end{array}$ \\
\hline
\end{tabular}

Panjang karapas atau CL S. tranquebarica rata-rata $62,65 \mathrm{~mm}$, nilai tengah $60,20 \mathrm{~mm}$ dan data tersebar paling banyak pada kisaran $51,20-78,20 \mathrm{~mm}$. Untuk $S$. serrata rata-rata 79,94 $\mathrm{mm}$, nilai tengah $81,05 \mathrm{~mm}$, data tersebar paling banyak pada kisaran 74,58-87,20 mm. Outlier 3 menunjukkan ukuran panjang terkecil yang ditemukan sebesar 54,20 dan outlier 30 menunjukkan panjang tertinggi yang bisa dicapai sebesar 109,20 mm. Panjang karapas S. paramamosain rata-rata $67,62 \mathrm{~mm}$, nilai tengah $70,15 \mathrm{~mm}$ dan data tersebar paling banyak pada kisaran $53,09-$ $79,95 \mathrm{~mm}$. Panjang karapas atau CL (Carapace Length) rata-rata tiap spesies yang tertangkap di kedua stasiun dapat di lihat pada Gambar 6.

Adapun rata-rata dan standar deviasi dari beberapa rasio morfologi dan bentuk duri antara mata untuk membedakan ketiga spesies kepiting bakau yang tertangkap selama penelitian, dapat dilihat pada Tabel 4 dan Gambar 7, 8 dan 9.

Pada Gambar 7 boxplot FMSH/FW, S. tranquebarica memiliki rata-rata $0,064 \mathrm{~mm}$, nilai tengah $0,067 \mathrm{~mm}$, dan data tersebar paling banyak pada kisaran $0,041-0,086 \mathrm{~mm}$. S. serrata memiliki rata-rata $0,079 \mathrm{~mm}$, nilai tengah $0,084 \mathrm{~mm}$, dan data tersebar paling banyak pada kisaran $0,072-0,092 \mathrm{~mm}$. S. paramamosain memiliki rata-rata $0,070 \mathrm{~mm}$, nilai tengah $0,073 \mathrm{~mm}$, dan data tersebar paling banyak pada kisaran $0,058-0,081 \mathrm{~mm}$.

Pada Gambar 8 boxplot FW/ICW, S. tranquebarica memiliki rata-rata $0,418 \mathrm{~mm}$, nilai tengah $0,415 \mathrm{~mm}$, dan data tersebar paling banyak pada kisaran $0,406-0,435 \mathrm{~mm}$. S. serrata memiliki rata-rata $0,393 \mathrm{~mm}$, nilai tengah $0,397 \mathrm{~mm}$, dan data tersebar paling banyak pada kisaran $0,392-0,402 \mathrm{~mm}$. S. paramamosain memiliki rata-rata $0,406 \mathrm{~mm}$, nilai tengah $0,416 \mathrm{~mm}$, dan data tersebar paling banyak pada kisaran $0,393-0,433 \mathrm{~mm}$.

Pada Gambar 9 boxplot ICS/OCS, S. tranquebarica memiliki rata-rata $0,352 \mathrm{~mm}$, nilai tengah $0,332 \mathrm{~mm}$, dan data tersebar paling banyak pada kisaran $0,210-0,434 \mathrm{~mm}$. S. serrata memiliki rata-rata $0,294 \mathrm{~mm}$, nilai tengah $0,298 \mathrm{~mm}$, dan data tersebar paling banyak pada kisaran $0,174-0,398 \mathrm{~mm}$. S. paramamosain memiliki rata-rata $0,325 \mathrm{~mm}$, nilai tengah $0,331 \mathrm{~mm}$, dan data tersebar paling banyak pada kisaran $0,235-0,372 \mathrm{~mm}$.

Bagi masyarakat yang tinggal di wilayah Belawan Medan, kepiting bakau yang tertangkap biasanya dijual kepada pengumpul atau di konsumsi sendiri. Adapun kelompok ukuran pasaran kepiting bakau yang tertangkap selama penelitian dapat di lihat pada Tabel 5. Beberapa hal yang perlu diketahui untuk menjual kepiting bakau kualitas ekspor kepada pengumpul adalah kepiting bakau jantan dengan berat $\geq 200$ gram per ekor dibeli dari penangkap dengan kisaran harga minimal Rp. 60.000,- per kilogram sedangkan kepiting bakau betina dengan berat $\geq 200$ gram per ekor dibeli dari penangkap dengan kisaran harga minimal Rp. 120.000,- per kilogram. Selain itu bentuk badan utuh dan capit tidak patah. Harga-harga tersebut adalah harga tertinggi pada bulan Februari 2012. Harga penjualan kepiting tidak selalu sama ditiap tempat dan ditiap waktu.

Tabel 4. Rata-rata dan standar deviasi dari beberapa rasio morfologi dan bentuk duri antara mata ketiga spesies kepiting bakau

\begin{tabular}{lccc}
\hline \multirow{2}{*}{ Rasio } & \multicolumn{3}{c}{ Rata-rata \pm SD } \\
\cline { 2 - 4 } & S. tranquebarica & S. serrata & S. paramamosain \\
\hline CW $(\mathrm{mm})$ & $101,847 \pm 21,236$ & $94,793 \pm 20,749$ & $119,724 \pm 18,703$ \\
ICW $(\mathrm{mm})$ & $96,375 \pm 19,953$ & $89,641 \pm 19,390$ & $114,080 \pm 18,033$ \\
CL $(\mathrm{mm})$ & $67,619 \pm 14,267$ & $62,646 \pm 13,857$ & $79,938 \pm 11,209$ \\
FMH/FW & $0,065 \pm 0,023$ & $0,071 \pm 0,016$ & $0,080 \pm 0,015$ \\
FW/ICW & $0,419 \pm 0,028$ & $0,407 \pm 0,043$ & $0394 \pm 0,023$ \\
ICS/OCS & $0,353 \pm 0,229$ & $0,325 \pm 0,133$ & $0,294 \pm 0,141$ \\
\hline
\end{tabular}




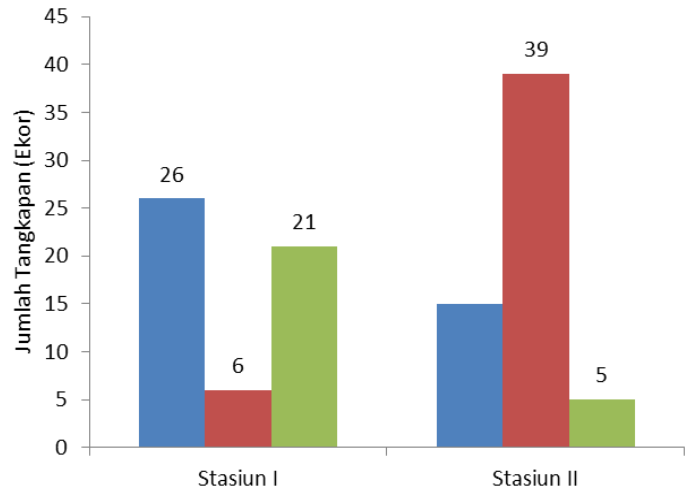

Gambar 1. Kisaran berat dan jenis kelamin kepiting bakau di setiap stasiun

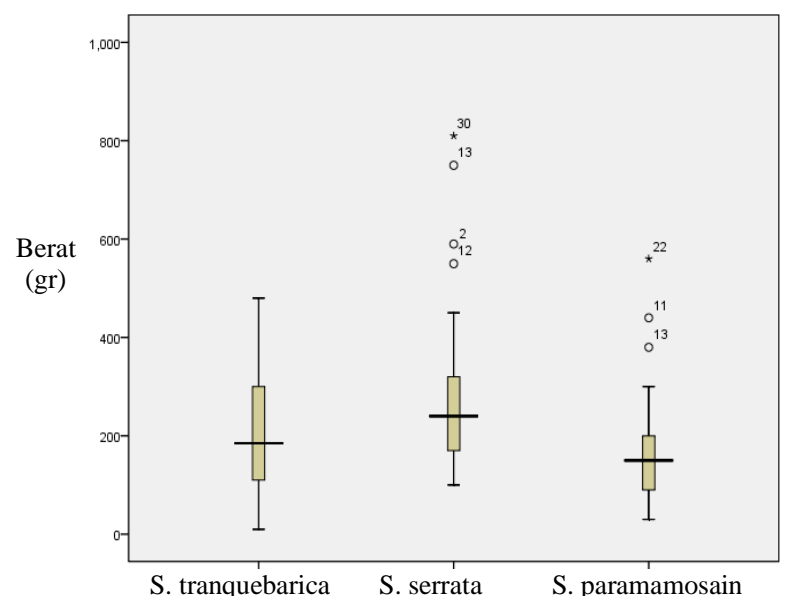

Gambar 3. Boxplot berat tiap spesies

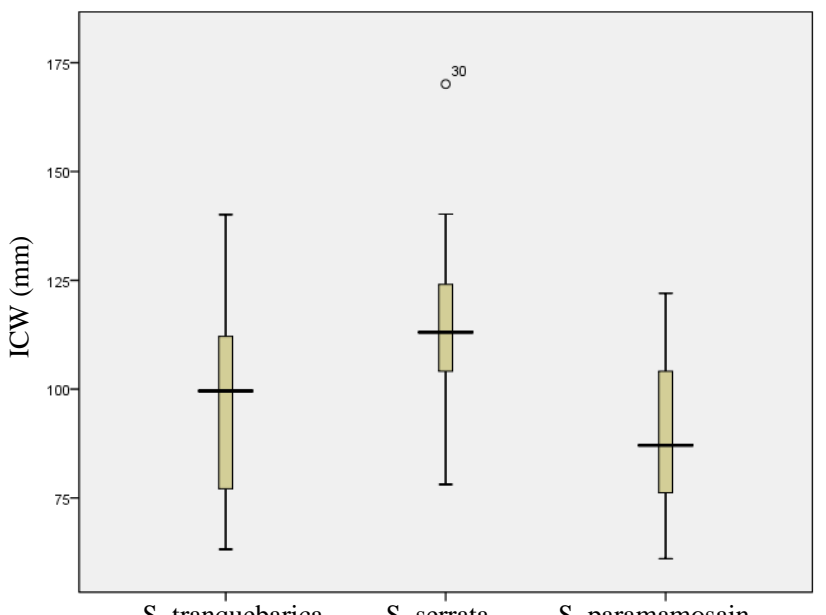

Gambar 5. Boxplot ICW tiap spesies

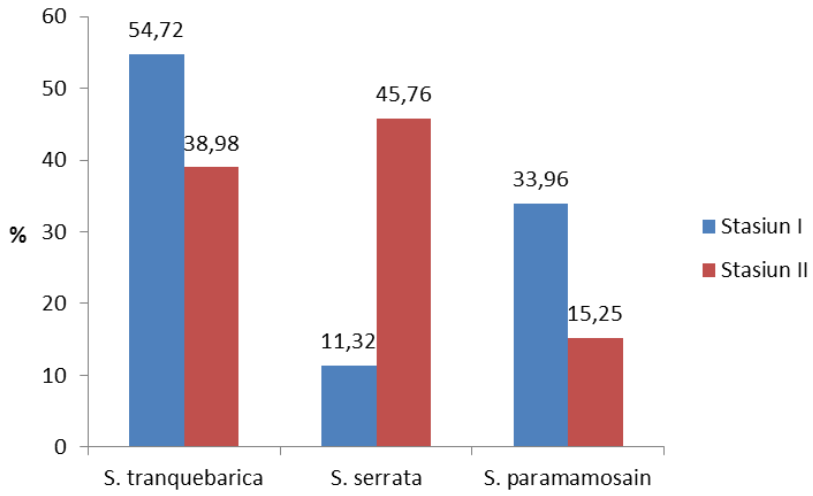

Gambar 2. Persentase jumlah spesies di tiap stasiun

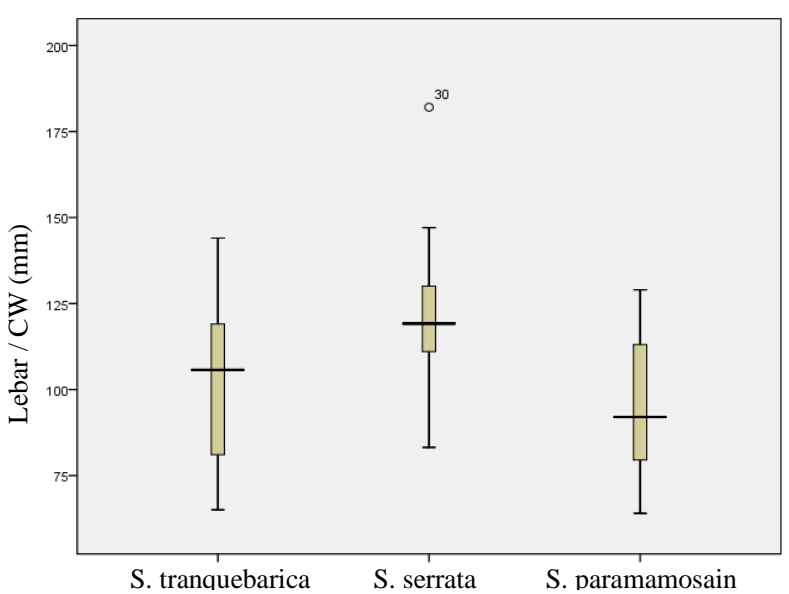

Gambar 4. Boxplot lebar karapas atau CW tiap spesies

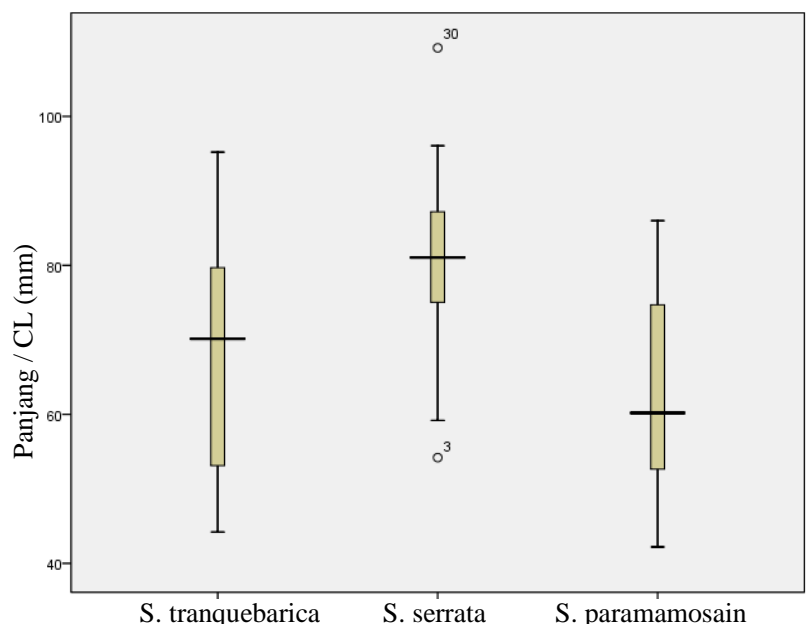

Gambar 6. Boxplot panjang atau CL tiap spesies 


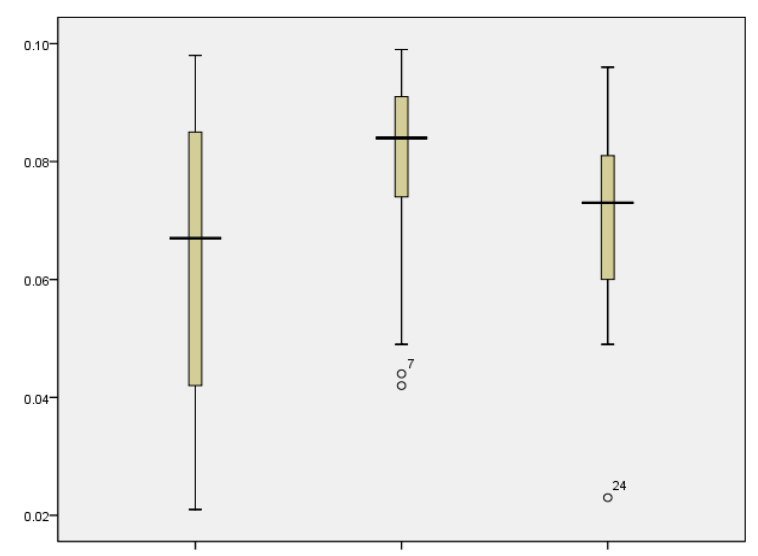

Gambar 7. tranquebarica. S. serrata Gambar 7. Boxplot rasio FMSH/FW tiap spesies

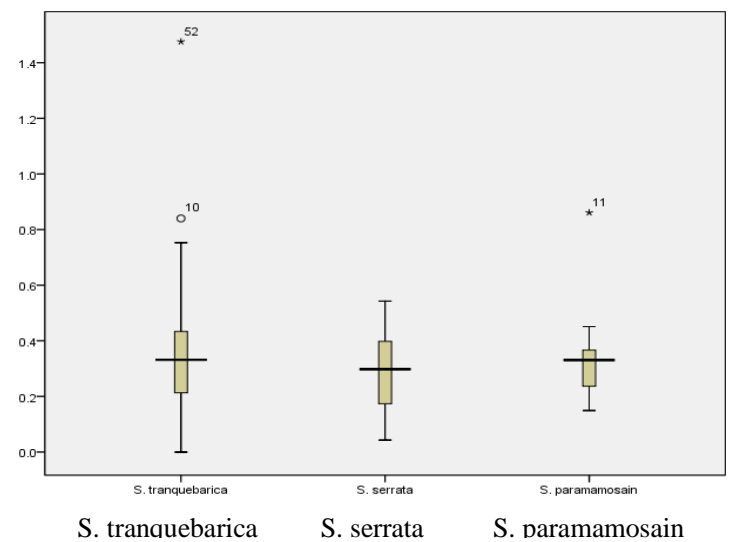

Gambar 9. Boxplot rasio hubungan ICS/OCS tiap spesies

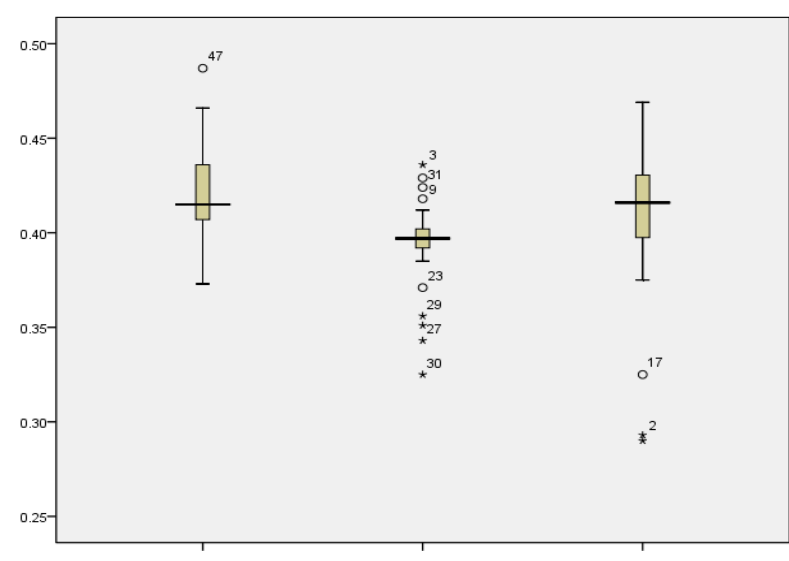

S. tranquebarica S. Serrata S. paramamosain Gambar 8. Boxplot rasio FW/ICW tiap spesies

Tabel 5. Ukuran ekonomi kepiting bakau

\begin{tabular}{llcc}
\hline Jenis kelamin & Kode & Kisaran berat (gram) & Jumlah (ekor) \\
\hline Jantan & CB & $\leq 50$ & 3 \\
& CH & $\geq 60$ & 4 \\
& CK & $100-150$ & 16 \\
& BS & $200-240$ & 4 \\
& A & $250-300$ & 2 \\
AA & $350-400$ & 5 \\
\hline \multirow{5}{*}{ Betina } & AS & $\geq 450$ & 6 \\
& CL & & 2 \\
& CLT (bertelur) & $150-180$ & 5 \\
& AC I (bertelur / jimbo) & $\geq 250$ & 2 \\
& AC II (betelur) & $200-240$ & 11 \\
& BL (tidak bertelur) & $\geq 250$ & 26 \\
\hline
\end{tabular}




\section{PEMBAHASAN}

Dari 112 sampel, diperoleh jantan dengan kisaran berat 40 - 750 gram, betina 110 - 810 gram, dan banci $30-200$ gram. Kisaran berat ini bervariasi, dikarenakan pada saat sampling peneliti mengambil sampel dengan metode penangkapan. Kepiting bakau yang diperoleh mulai dari yang berukuran kecil, sampai berukuran besar.

Jenis Scylla yang diperoleh pada saat penelitian ada tiga jenis yaitu, S. tranquebarica, S. paramamosain, dan $S$. serrata. Jenis yang ditemukan dalam penelitian ini berdasarkan tajam atau tumpulnya duri bagian frontal margin dan mereduksi atau ada tidaknya duri pada carpus di capitnya.

Menurut Carpenter dan Niem (1998), duri pada carpus dan gigi pada frontal margin merupakan bagian dari morfologi kepiting bakau (Scylla spp.) yang merupakan penentu jenis Scylla. Pengelompokan Scylla diawali dengan gigi anterolateral akhir sama dengan gigi-gigi yang lain pada daerah ini. Kemudian mulai terbagi pada daerah carpus dari cheliped, dimana yang pertama, carpus dari cheliped terdiri dari/ hanya satu duri yang mereduksi pada permukaan luarnya, dan capit bewarna kuning dan orange. Kedua, carpus dari cheliped terdiri dari dua duri tajam pada permukaan luarnya, dan capit bewarna hijau atau ungu. Duri carpus pertama dipecah menjadi dua,terlihat dari bagian frontal pada karapasnya.

Jika bagian frontal terdiri dari gigi-gigi tumpul dan pada capit memiliki duri-duri yang tajam, begitu juga dengan carpusnya memiliki dua duri tajam. Karapas biasanya bewarna hijau tua atau coklat kehitaman. Capit dan kaki jalan bewarna ungu kecoklatan, pola tidak teratur, maka ciri-ciri tersebut merupakan jenis $S$. tranquebarica. Pada pleopod jantan terdapat pola marmer pada capit (Carpenter dan Niem, 1998).

S. paramamosain mempunyai 6 duri diantara mata yang berbentuk segitiga yang tajam dan duri yang nyata pada bagian propodus, sedangkan pada bagian carpus duri tampak tereduksi (kecil). Hal ini sesuai dengan Keenan et al (1998) yang menyatakan bahwa ciri dari S. paramamosain adalah memiliki sepasang duri yang tidak terlalu tampak jelas pada propodus, duri pada ICS dan OCS juga tereduksi.

Jika memiliki gigi-gigi tajam pada bagian frontal dan memiliki dua duri carpus yang juga tajam, maka ciri-ciri tersebut merupakan jenis S. serrata. Selain itu pada capit memiliki duri yang tajam dan warna karapas biasanya bewarna hijau tua sampai hijau kehitaman (gelap). Bagian luar capit bewarna hijau kebiruan dan memiliki pola marmer. Kaki renang baik jantan maupun betina memiliki pola yang sama (Carpenter dan Niem, 1998).

Histogram jumlah tangkapan kepiting bakau di dua stasiun pada Gambar 1 menunjukkan kepiting bakau betina lebih mendominasi di stasiun II sedangkan kepiting bakau jantan lebih mendominasi di stasiun I, sehingga dapat diduga pada saat itu kepiting bakau mulai memasuki musim kawin atau pemijahan. Kepiting bakau umumnya memijah di perairan laut. Arriolla dan Brick, yang diacu oleh Siahainenia (2008) menyatakan bahwa kepiting bakau bertelur akan bermigrasi dari perairan payau ke perairan laut untuk memijah.

Jenis $S$. tranquebarica mendominasi, jumlah spesies ini sangat banyak dibandingkan spesies lain di kedua stasiun (lihat Gambar 2). Kepiting bakau S. tranquebarica banyak dijumpai hidup di tepi pantai yang tanahnya agak berlumpur, dimana daerah ini merupakan daerah pasang surut, selain itu kepiting bakau ini biasanya ditemukan berasosiasi dengan kepiting bakau $S$. olivacea. Tempat yang paling disenangi oleh kepiting ini adalah pantai dangkal yang memiliki tumbuh-tumbuhan mangrove seperti hutan bakau dan nipah (Afrianto, 1992 dan Keenan, 1998).

Kepiting bakau S. tranquebarica tersebar luas di bagian barat Indo Pasifik yakni daerah Pakistan ke Malaysia dan Filipina, serta sangat berlimpah mengelilingi bagian selatan Laut Cina Selatan (Keenan, 1998).

Beberapa hal tentang ciri kepiting bakau yang tertangkap di Perairan Labuhan Bahari Belawan Medan dapat dilihat pada Gambar 3 sampai 6 yang berisi boxplot berat, CW, ICW, dan CL. Dari seluruh boxplot tersebut dapat dilihat $S$. tranquebarica memiliki sebaran data yang lebih besar dibandingkan kedua spesies lainnya. Dilihat dari bobot berat, panjang, dan lebar karapas kepiting yang tertangkap adalah kepiting muda. Besarnya ukuran kepiting belum tentu mempengaruhi berat, disebabkan oleh kemungkinan dari proses moulting Scylla, sehingga sering ditemukan ukuran Scylla yang besar, tetapi beratnya kecil. Ukuran dari masing masing jenis beragam. Misalnya S. serrata dapat mencapai $3 \mathrm{~kg}$ maupun ukuran $2 \mathrm{~kg}$ yang dapat dicapai S. tranquebarica dan S. paramamosain (Carpenter dan Niem, 1998).

Rata-rata dan standar deviasi dari beberapa rasio morfologi dan bentuk duri antara mata ketiga spesies kepiting bakau (lihat Tabel 3 dan Gambar 7 sampai 9 kemudian dibandingkan dengan rata-rata dan standar deviasi hasil penelitian dari Keenan et al (1998). Terdapat beberapa nilai rata-rata dan standar deviasi yang hampir mendekati dengan referensi Keenan et al (1998). Hal ini karena pada penelitian selain menggunakan perhitungan terhadap morfologi kepiting, sebelumnya tiap kepiting sudah diidentifikasi bagian duri diantara mata dan warna karapas yang dapat menunjukkan jenis kepiting tersebut. Sehingga apabila terjadi perbedaan nilai perbandingan morfologinya dengan referensi Keenan et al (1998), maka identifikasi pengamatan duri dapat digunakan.

Hasil penelitian ini dimana ditemukan tiga jenis kepiting bakau di Perairan Labuhan Bahari Belawan Medan yang menunjukkan hasil yang sama dengan hasil penelitian dari Miswar (2000) di Sumatera Utara dan Pary (2010) di Maluku. Dalam penelitian yang dilakukan Miswar (2000) di Suaka Margasatwa Karang Gading, Sumatera Utara dijelaskan bahwa dijumpai tiga jenis Kepiting Bakau disetiap stasiun pengamatannya yaitu S. serrata, S. tranquebarica, dan S. paramamosain. Dalam penelitian lain yang dilakukan di Teluk Kotania, Kabupaten Seram, Maluku oleh Pary (2010) didapatkan Kepiting Bakau sebanyak 3 spesies yakni S. serrata, S. paramamosain, dan S. tranquebarica. Ini 
menunjukkan bahwa ketiga jenis kepiting bakau tersebut mempunyai distribusi yang cukup luas khususnya di Pulau Sumatera dan Kepulauan Maluku.

Menurut Le Vay (2001), kepiting bakau banyak ditemukan didaerah estuari dan daerah pesisir yang terlindungi. Pada umumnya, populasi kepiting bakau berasosiasi dengan hutan mangrove. Namun, penyebaran dan kelimpahan 4 spesies kepiting bakau kemungkinan lebih kompleks. Pendapat ini diperkuat oleh Keenan et al (1998) yang menyatakan bahwa habitat $S$. paramamosain berasosiasi dengan hutan mangrove dan garis pantai yang terendam dengan salinitas air laut lebih rendah dari air laut hampir sepanjang tahun. Spesies ini sering dilaporkan terdapat didaerah estuarin.

Penelitian yang dilakukan Pary (2010) mengenai kepadatan kepiting bakau, ia menemukan tiga spesies kepiting bakau di Kabupaten Seram, Maluku dengan komposisi tertinggi sampai terendah S. serrata, S. paramamosain, terakhir S. tranquebarica. Spesies S. serrata merupakan spesies yang paling tinggi kepadatannya di Maluku diduga karena perbedaan lokasi antara Kepulauan Maluku dan Kepulauan Riau. Hal ini berbanding lurus dengan penelitian yang dilakukan Hendrarto (2012) di Kendal, Semarang, Bonang, Wedung, dan Rembang dimana ditemukan tiga spesies Kepiting Bakau dengan distribusi $S$. paramamosain yang paling merata.

Kepiting bakau $S$. tranquebarica banyak dijumpai hidup di tepi pantai yang tanahnya agak berlumpur, dimana daerah ini merupakan daerah pasang surut, selain itu kepiting bakau ini biasanya ditemukan berasosiasi dengan kepiting bakau S. olivacea. Tempat yang paling disenangai oleh kepiting ini adalah pantai dangkal yang memiliki tumbuhtumbuhan mangrove seperti hutan bakau dan nipah (Afriyanto, 1992 dan Keenan, 1998). Kepiting bakau $S$. tranquebarica tersebar luas di bagian barat Indo-Pasifik yakni dari daerah Pakistan ke Malaysia dan Filipina, serta sangat berlimpah mengelilingi bagian selatan Laut Cina Selatan (Keenan, 1998).

Harga kepiting tidak selalu sama setiap waktu maupun setiap daerah. Harga kepiting sering mengalami perubahan, hal ini disebabkan oleh permintaan pasar dan musim. Seperti saat Imlek dan Cap Gomeh, permintaan terhadap kepiting di Taiwan sangat tinggi sehingga sering mengimpor dari Indonesia. Begitu juga pada saat musim dingin di Jepang permintaan terhadap kepiting kaleng (kepiting soka) sangat tinggi. Akibat dari besarnya permintaan, maka harga kepiting dipasaran menjadi tinggi. Selain faktor minat pasar, musim kawin juga mempengaruhi harga kepiting karena kepiting jarang ditemukan untuk ditangkap.

Kepiting bakau adalah salah satu komoditi perikanan yang mudah dalam pemasaran asalkan sesuai dengan kriteria antara lain berat 250-500 gram per ekor, bentuk badan utuh dan capit tidak patah. Kepiting yang mempunyai harga tinggi diantaranya adalah kepiting bakau merah dan hitam. Di Kalimantan Timur harga kepiting super big size mencapai Rp. 70.000,- sampai dengan Rp. 95.000,- per kilogram di tingkat pengepul, sedangkan kepiting bakau hijau hanya Rp. 15.000,- sampai dengan Rp. 20.000,- per kilogram (www.defishery.worpress.com/fish-pricelist)

Kepiting yang memiliki berat $\leq 150$ gram yang tertangkap pada saat penelitian biasanya oleh penangkap dikonsumsi sendiri, dijual di pasar, atau dibuat menjadi kepiting soka. Untuk pemasaran kepiting cangkang lunak ini sangat luas pemasarannya, di dalam negeri saja belum dapat dipenuhi. Pemasaran dalam negeri kepiting ini dipasarkan di wilayah Medan, Jakarta, Surabaya dan Bandung dengan harga Rp. 60.000,- sampai Rp. 65.000,-. Untuk permintaan luar negeri kepiting sebelumnya ditampung di pabrik (cool storage) di Kawasan Industri Medan (KIM), setelah memenuhi syarat ekspor baru dikirim dalam kontainer. Permintaan pasar luar negeri seperti Jepang, Amerika Serikat, Singapura dan Malaysia harganya pun lebih tinggi dibandingkan kepiting biasa karena komoditas ini adalah seluruh organ tubuhnya lunak sehingga dapat dimakan secara keseluruhan tanpa harus susah payah memisahkan antara daging dan cangkangnya (www.ukmkecil.com/budidaya-ternak/budidaya-kepiting-soka).

Melihat jenis mangrove yang tumbuh di stasiun I penelitian yaitu jenis dari genera Rhizopora dan Avicenia menunjukkan kedua tanaman mangrove tersebut tumbuh di zona mangrove terbuka, sedangkan di stasiun II penelitian yang didominasi oleh genera Nypha menunjukkan pertumbuhannya masuk dalam zona mangrove daratan.

Berdasarkan penelitian yang dilakukan, suhu di kedua stasiun berkisar antara $27^{\circ} \mathrm{C}-29^{\circ} \mathrm{C}$. Kisaran suhu ini dapat ditoleransi bagi pertumbuhan dan keberadaan Kepiting Bakau. Suhu air di kedua stasiun stabil yaitu tidak ada perubahan yang drastis. Perubahan suhu yang drastis (naik ataupun turun) dapat mempengaruhi tingkat kelarutan oksigen dalam air dan metabolisme Kepiting Bakau. Dalam jurnal Pratiwi (2009) yang berjudul Komposisi Keberadaan Krustasea di Mangrove Delta Mahakam Kalimantan Timur kisaran suhu pada lokasi penelitiannya adalah $25^{\circ} \mathrm{C}-29^{\circ} \mathrm{C}$, menurutnya kisaran tersebut tergolong normal untuk kehidupan krustasea khususnya kepiting.

Nilai salinitas di kedua stasiun berkisar antara 12-25 ppt. Tinggi dan rendah kisaran nilai salinitas di kedua stasiun disebabkan karena pencampuran antara air tawar dan air laut. Kisaran salinitas 23 ppt-30 ppt sesuai dengan baku mutu air laut bagi biota menurut Keputusan Menteri Lingkungan Hidup Nomor 51 Tahun 2004 yaitu 10-30 ppt, artinya kisaran salinitas di kedua stasiun dapat ditoleransi oleh Kepiting Bakau untuk mendukung tumbuh dan berkembangnya kepiting.

Kisaran pH perairan yang didapatkan dari hasil penelitian di kedua stasiun adalah berkisar antara 6,5-7,2. Kisaran pH perairan 7-7,6 merupakan kisaran yang dapat ditoleransi bagi pertumbuhan Kepiting Bakau. Pada penelitian yang dilakukan oleh Pertiwi pada tahun 2005, nilai pH perairan di lokasi penelitian (Kalimantan Timur) berkisar antara 6,27,5 dan nilai ini normal bagi Kepiting Bakau. Menurut Sari (2004) dalam penelitiannya pada habitat mangrove Ulee Lheue (Banda Aceh) mendapatkan nilai pH perairan pada kisaran 6,09-7,83 yang juga tergolong dalam keadaan normal dan baik untuk kehidupan kepiting. 


\section{KESIMPULAN}

Kesimpulan yang dapat diambil setelah melakukan penelitian ini adalah sebagai berikut:

1. Jenis kepiting bakau yang ditemukan kedua stasiun pada saat penelitian adalah S. tranquebarica, S. paramamosain, dan S. serrata dan yang paling mendominasi di Perairan Labuhan Bahari Belawan Medan adalah jenis $S$. tranquebarica.

2. Pengamatan duri frontal atau duri diantara mata, duri carpus, serta didukung dengan perhitungan rasio ICS/OCS, FMSH/FW dan FW/ICW adalah teknik identifikasi yang cepat untuk menentukan spesies kepiting bakau.

3. Kepiting bakau dengan berat $\geq 200$ gram per ekor adalah komoditi perikanan yang sangat diminati dan mudah untuk dipasarkan di dalam negeri maupun di ekspor, serta harga jualnya tergantung pada minat pasar dan musim.

\section{Saran}

Saran yang dapat saya berikan sesuai dengan penelitian ini adalah:

1. Mengingat penelitian dilakukan pada siang hari, maka diperlukan penelitian lebih lanjut, khususnya berdasarkan waktu sampling pada malam hari karena kepiting bakau bersifat nocturnal.

2. Penangkapan hanya boleh dilakukan terhadap kepiting yang sudah layak konsumsi, sehingga kepiting yang masih kecil dapat berkembangbiak dan populasi kepiting tetap terjaga.

3. Kepiting bakau dengan berat $\geq 200$ gram per ekor adalah komoditi perikanan yang sangat diminati dan mudah untuk dipasarkan di dalam negeri maupun di ekspor, serta harga jualnya tergantung pada minat pasar dan musim.

\section{UCAPAN TERIMAKASIH}

Pada kesempatan ini penulis mengucapkan banyak terimakasih kepada Dr. Drs. Ign. Boedi Hendrarto, MSc dan Dr. Ir. Haeruddin, Msi yang telah membantu dalam penyusunan penulisan ini, serta keluarga dan teman-teman yang turut berpartisipasi dalam penelitian dan terus memberikan dukungan.

\section{DAFTAR PUSTAKA}

Afrianto,E dan Liviawaty, E. 1992. Pemeliharaan Kepiting. Penerbit Kanius. Yogyakarta.

Carpenter, K. E and Niem, C. H. 1998. The Living Marine Resources of the Western Central Pacific. Volume 2. Food and Agriculture Organization of the United Nations, Rome, Pp 1118 - 1128.

Cowman, L. 1984. Crab Farming in Japan,Taiwan and Philippines. Quendsland Departement. International of Primary Industries. Brisbane.

Hadi, S. 1980. Metodologi Penelitian. Penerbit Ghalia Indonesia. Jakarta.

Heasman, M.P. and Fielder.D.R. 1983. Laboratory Spawning and Mass Rearing of the Mangrove Crab, S. serrata (Forskal) From First Zoea to First Crab.

Hendrarto, B. 2012. Species and Some Ecological Aspects of Mangrove Crabs in Mangrove Ecosystems of Central Java's North Coast: (1) Kendal, Semarang, Wedung, Rembang. Universitas Diponegoro.

Kasry, A. 1996. Budidaya Kepiting Bakau Dan Biologi Ringkas. Bhatara. Jakarta.

Keenan, C. P. And A. Blackshaw. 1998. Mud Crab Aquaculture and Biology. Australian Centre for International Agricultural Research. Canberra.

1999. Aquaculture of the Mud Crab, Genus Scylla. Past, Present and Future in: Mud Crab Aquaculture and Biology Keenan and Blackshaw (Eds) ACIAR Proceedings, 78 : 9-13.

Kordi, M.G, 2000. Budidaya Kepiting dan Ikan Bandeng di Tambak Sistem Polikultur. Penerbit Dahara Prize. Semarang.

LeVay, L. 2001. Ecology and Management of Mud Crab Scylla spp. Asian Fisheries Science 14: 101-111.

Nazir, M. 2005. Metode Penelitian. Ghalia Indonesia. Jakarta.

Moosa, M. K . 1985. Kepiting Bakau (S. serrata. Forskal) Dari Perairan Indonesia. Proyek Studi Potensi Sumberdaya Alam Indonesia. Lembaga Oseanologi Nasional, Lembaga Ilmu Pengatahuan Indonesia. Jakarta.

Prianto, E. 2007. Peran Kepiting Sebagai Spesies Kunci (Keystone Spesies) pada Ekosistem Mangrove. Prosiding Forum Perairan Umum Indonesia IV. Balai Riset Perikanan Perairan Umum. Banyuasin.

Rosmaniar. 2008. Kepadatan Dan Distribusi Kepiting Bakau (Scylla sp.) Serta Huungannya Dengan Faktor Fisik Kimia Di Perairan Pantai Labu Kabupaten Deli Serdang. (Tesis). Pascasarjana USU, Medan, 78 hlm.

Rusila Noor, Y., M. Khazali, dan I. N. N. Suryadiputra. 1999. Panduan Pengenalan Mangrove di Indonesia. PKA/WIIP. Bogor, 186 hlm.

Sainsbury, J. C. 1996. Commercial Fishing Methods 3e - an Introduction To Vessels and Gears (Fishing News Books). Unipub

Sato, N. 2004. Pengaruh Perbedaan Jenis Bubu dan Jenis Umpan Terhadap Hasil Tangkapan di Perairan Rawa Pening Kabupaten Semarang. (Skripsi). Fakultas Perikanan dan Ilmu Kelautan, Undip, Semarang, 9 hlm.

Shimek, R. L. 2008. Crabs, (Online), www.reefkeeping.com (diakses 20 Oktober 2010).

Siahainenia, L. 2008. Bioekologi Kepiting Bakau (Scylla spp.) Di Ekosistem Mangrove Kabupaten Subang Jawa Barat. (Disertasi S3). Sekolah Pascasarjana IPB. Bogor. 
Soim, A. 1993. Pembesaran Kepiting. Penebar Swadaya, Jakarta.

Sudirman dan Achmar, M. 2004. Teknik Penangkapan Ikan. Rineka Cipta. Jakarta.

Sulistiono, S. Watanabe and S. Tsuchida. 1992. Biology And Fisheries of Crab in Segara Anakan Lagoon (Tidak Dipublikasikan). Makalah Hasil Penelitian Bersama antara Fakultas Perikanan IPB dengan Departement of Aquatic Bio Sciences, Tokyo University of Fisheries.

Von Brandt, A. 1984. Fish Catching Methods of The World. Third Edition. Fishing News Book. Farnham.

www.defishery.worpress.com/fish-pricelist (diakses tanggal 22 Mei 2013)

www.labuhanbahari.com/lokasi (diakses tanggal 15 Juni 2013)

www.ukmkecil.com/budidaya-ternak/budidaya-kepiting-soka (diakses tanggal 22 Mei 2013) 